\title{
RANCANG BANGUN SISTEM KONTROL ROBOT LINE FOLLOWER MENGGUNAKAN LOGIKA FUZZY
}

\author{
Anggoro Mukti. ${ }^{1)}$, Oky Dwi Nurhayati ${ }^{2)}$, Eko Didik Widianto ${ }^{2)}$ \\ Program Studi Sistem Komputer, Fakultas Teknik, Universitas Diponegoro \\ Jalan Prof. Sudharto, Tembalang, Semarang, Indonesia
}

\begin{abstract}
Line follower robot is a robot that can follow a line composed of a series of electronic components are equipped with wheels and driven by a motor. Controlling speed is very dependent on the speed limit and friction between the tire robot with the floor. The robots are designed to navigate and move automatically follow a flow line in order to get a response and speed are ideal..

The system consists of hardware and software. The hardware consists of a sensor such as a photodiode input, ATMEGA32 as microcontroller and DC motors. fuzzy logic is divided into three processes namely fuzzyfikasi, evaluation and defuzzyfikasi rule. Defuzzification a conversion step in fuzzy logic system to keluaran crisp value. The conversion result is an action taken by Fuzzy logic control system.

The test results were obtained system is capable of identifying a straight line, turn lanes, and lane gray. The system is able to provide an ideal response and speed. input from the reading of the line will be processed by the control system fuzzy and outputs the result as the calculating of the motor speed. fuzzy control system can be an alternative technology development line follower robot control system.
\end{abstract}

Keywords: Robotic, fuzzy logic, line follower robot, FLC.

\section{PENDAHULUAN}

Robot adalah sebuah piranti mekanik yang mampu melakukan pekerjaan manusia atau berperilaku seperti manusia ${ }^{[1]}$. Robot dirancang manusia untuk membantu manusia dalam melakukan pekerjaan yang memiliki ketelitian tinggi, resiko tinggi, dan terus menerus serta dengan tenaga yang besar. Bedasarkan proses kendalinya, robot terbagi menjadi dua jenis yaitu robot otomatis dan robot teleoperasi ${ }^{[2]}$. Robot yang digunakan adalah robot pengikut garis. Robot mendeteksi garis dengan cara mengukur intensitas cahaya yang dipantulkan dari permukaan yang dilaluinya ${ }^{[3]}$

Logika fuzzy adalah peningkatan dari logika Boolean, yang mempunyai kesamaan dengan kebenaran sebagian. Logika fuzzy dapat berguna menentukan nilai antara 0 dan 1. Logika fuzzy tidak sama dengan logika klasik. Logika fuzzy berhubungan dengan ketidaksamaan, ketidakpastian dan kebenaran sebagian. Alasan inilah yang membuat lebih mudah mengimplementasikan kontrol logika fuzzy untuk model linear, dibandingkan dengan teknik kontrol konvensional lainnya ${ }^{[2]}$.
Pada perancangan robot pengikut jalur dapat mengaplikasikan logika fuzzy sebagai sistem kontrol di dalamnya. Seperti banyak kasus dalam robot pengikut jalur, pergerakan robot tidak stabil karena diberikan nilai acuan yang sensitif. Jika nilai acuan dibuat kurang sensitiv terhadap respon, maka akan terjadi proses pemulihan yang memerlukan waktu lebih lama. Sehingga akan menyebabkan pergerakan robot yang semakin kacau. Logika fuzzy berfungsi untuk membantu menentukan parameter pengambilan nilai sensor yang nantinya akan diolah menjadi keluaran berupa kecepatan untuk menentukan posisi ideal robot.

Dengan berdasarkan permasalahan yang telah tesebut diatas maka akan dirancang sistem kontrol robot pengikut jalur dengan menggunakan logika fuzzy.

Adapun tujuan penelitian yang akan dicapai adalah untuk tmenghasilkan sebuah rancang bangun sebuah sistem kontrol robot line follower dengan logika fuzzy.

Untuk menghindari pembahasan yang meluas, maka dalam Tugas Akhir ini ditetapkan batasan-batasan masalah. Pertama robot yang digunakan adalah robot berbentuk mobil dengan Deteksi jalur robot menggunakan sensor fotodioda. Kedua proses logika fuzzy menggunaka fungsi keanggotaan segitiga, dua trapesium, dan defizifikasi menggunakan WOA (Wight of Average). Ketiga Jalur robot pada bidang datar dengan tingkat kesulitan tertentu, gerak robot lurus, belok, dan tidak melewati rintangan.

\section{METODE PENELITIAN}

Pada bagian ini akan dijabarkan mengenai kebutuhan dan metode yang digunakan untuk merancang perangkat keras dan perangkat lunak sistem. Perancangan diperlukan untuk memberikan metode dan tahapan yang jelas untuk membuat sistem sesuai dengan tujuan yang telah ditentukan. Perancangan yang akan dibahas adalah tentang identifikasi kebutuhan sistem, perancangan perangkat keras, perancangan perangkat lunak, implementasi perangkat keras dan perangkat lunak, dan pengujian sistem.

Perancangan kebutuhan sistem adalah sistem dapat menerima masukan berupa jalur hitam dengan latar putih, sistem dapat melakukan mekanisme inferensi fuzzy dari masukan yang didapat, mekanisme inferensi fuzzy pada sistem dilakukan secara berulang sampai robot keadaan mati, sistem dapat menghasilkan keluaran berupa konstanta untuk perhitungan kecepatan putaran roda. 
Perangkat keras yang digunakan adalah robot pengikut garis sederhana. Terdiri dari mikrokontroler, sensor fotodioda, dan motor dc.

Perancangan perangkat lunak adalah merancang sistem kontrol logika fuzzy pada robot pengikut garis, mulai dari fuzzyfikasi, basis aturan, defuzzyfikasi, dan perhitungan kecepatan roda.

Implemetasi perangkat keras dan perangkat lunak adalah mewujudkan perancangan-perancangan yang telah dibuat. Komponen perangkat keras dirakit dan ditempatkan pada sebuah papan akrilik. Hasil rancangan perangkat lunak dibuat kedalam bahasa pemrograman. Setelah mengimplementasi perangkat keras dan perangkat lunak adalah pengujian sistem.

Mikrokontroler merupakan sebuah sistem komputer yang dibangun pada sebuah keping (chip) tunggal $^{[4]}$, mikrokontroler yang digunakan adalah ATMEGA32. Sensor fotodioda digunakan sebagai pembaca jalur dari pantulan cahaya jalur yang akan dikonversi menjadi arus ${ }^{[5]}$. Motor dc digunakan untuk penggerak robot dengan mengkonversi besaran listrik menjadi besaran mekanik ${ }^{[6]}$.

\section{PERANCANGAN SISTEM}

Pada bagian ini akan dijabarkan mengenai kebutuhan dan metode yang digunakan untuk merancang perangkat keras dan perangkat lunak sistem. Perancangan diperlukan untuk memberikan metode dan tahapan yang jelas untuk membuat sistem sesuai dengan tujuan yang telah ditentukan. Perancangan yang akan dibahas adalah tentang identifikasi kebutuhan sistem, mikrokontroler ATMEGA32, dan perancangan kendali fuzzy.

Proses ini dibutuhkan untuk melakukan proses identifikasi dan proses analisa kebutuhan-kebutuhan yang diperlukan untuk membuat sistem. Kebutuhan-kebutuhan tersebut terdiri atas kebutuhan fungsional dan nonfungsional, yang dijelaskan sebagai berikut.

Kebutuhan fungsional dalam perancangan sistem adalah pertama sistem dapat menerima masukan berupa jalur hitam dengan latar putih. Kedua, sistem dapat melakukan mekanisme inferensi fuzzy dari masukan yang didapat. Ketiga, mekanisme inferensi fuzzy pada sistem dilakukan secara berulang sampai robot keadaan mati. Keempat, sistem dapat menghasilkan keluaran berupa konstanta untuk perhitungan kecepatan putaran roda.

Kebutuhan non-fungsional perancangan sistem adalah pertama perangkat keras sensor fotodioda, untuk masukan jalur. Kedua, perangkat keras LED putih, untuk membantu masukan jalur. Ketiga, perangkat keras servo motor, untuk pengendali kecepatan roda.

Proses perancangan perangkat keras akan menjabarkan rancangan perangkat keras yang akan digunakan untuk membuat sistem, mulai dari perangkat keras utama yang dibutuhkan sistem hingga instrumeninstrumen elektronika pendukungnya. Perancangan perangkat keras terdiri dari perancangan sistem minimum mikrokontroler ATMEGA32. Penggunaan pin pada

Mikrokontroler adalah pusat dari semua instruksi masukan maupun keluaran dari keseluruhan fungsi robot. Sistem minimum dari rangkaian mikrokontroler ATMega
32 yang digunakan pada robot ditunjukkan pada Gambar 3.

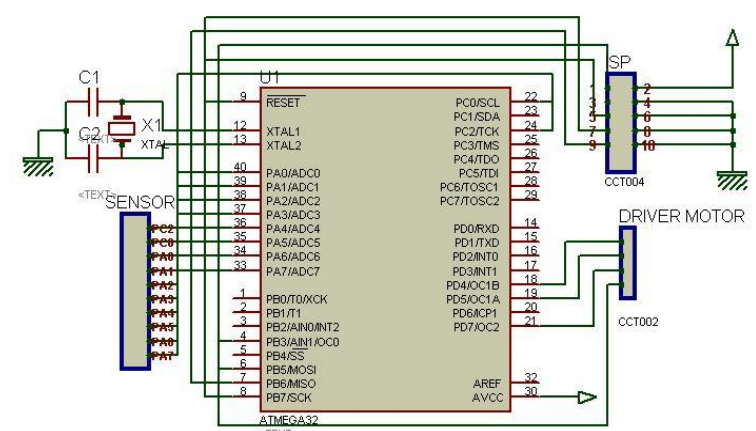

Gambar 3 Sistem minimum ATMEGA32

Mikrokontroler Atmega 32 mempunyai 4 buah Port, yang masing -masing Port terdiri dari 8 bit Port I/O. Port tersebut antara lain adalah Port A, Port B, Port C, dan Port D. Port A memiliki fungsi ganda, yaitu sebagai I/O, juga berfungsi sebagai ADC (Analog to Digital Converter). ADC berperan sebagai pengubah sinyal analog menjadi sinyal digital. Adapun pembagian kerja Port pada aplikasi mikrokontroler Atmega32 sebagai pengendali Robot Pengikut Garis adalah sebagai berikut:

Port (A0-A7) digunakan untuk menghubungkan mikrokontroler dengan 6 Sensor. Port (B3, D4, D5, D7 )digunakan untuk menghubungkan mikrokontroler Driver Motor.

Perancangan kendali fuzzy digunakan untuk memberikan tahapan yang jelas dalam pembuatan program yang akan mengendalikan perangkat keras dan menjadi otak yang menerima masukan dari sensor.

Sistem terlebih dahulu menerima masukan dari enam buah sensor. Masukan enam buah sensor dijadikan masukan pengendali logika fuzzy. Proses logika fuzzy terdiri dari tiga bagian yaitu fuzzyfikasi, logika pengambilan keputusan, dan defuzzyfikasi. Hasil pemrosesan logika fuzzy akan menjadi masukan yang berupa konstanta dari sistem kontrol proposianal, yang kemudian keluarannya akan menghasilkan kecepatan motor.

Fuzzyfikasi menjadi ciri utama dalam penalaran logika fuzzy ${ }^{[7]}$. Masukan yang didapat dari sensor berupa analog akan dijadikan digital untuk dapat diproses. Masukan yang berbentuk tegas dipetakan menjadi nilai linguistik yang mempunyai derajat keanggotaan antara 0 dan 1, sehingga didapatkan himpunan fuzzy. Sensor yang digunakan sebanyak 6 sensor. Masukan terdiri dari dua buah kurva, berbentuk trapesium dan kurva berbentuk segitiga. Fungsi keanggotaan sensor ditunjukan pada gambar 4 .

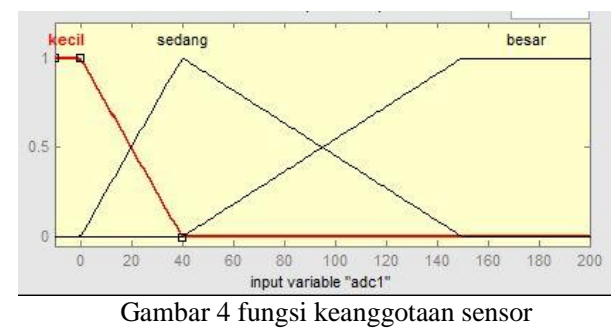


Basis aturan fuzzy diturunkan dari analisis perilaku sistem yang ditinjau. Basis aturan memuat aturan yang diharapkan untuk mencapai tujuan pengontrolan. Fungsi keanggotaan keluaran menggunakan fungsi singleton, sehingga mempercepat perhitungan ${ }^{[8]}$.

Nilai fuzzy yang berasal dari aturan basis pengetahuan dimasukkan ke dalam suatu membership function keluaran. Bentuk bangun yang digunakan dalam membership function keluaran adalah bentuk singleton yaitu garis lurus vertikal keatas. Nilai-nilai tersebut dimsukkan kedalam rumus metode WOA(Weigth of Average).

Perancangan keluaran kecepatan motor robot pengikut garis dibagi menjadi 2 kondisi umum, kondisi jalur lurus dan kondisi jalur belok. Pada kondisi jalur lurus robot dianggap berada pada kecepatan ideal yang sudah ditentukan, tidak menggunakan sistem kontrol fuzzy, dan ketika berada dalam kondisi jalur belok robot menggunakan sistem kontrol fuzzy untuk mendapatkan kecepatan motor robot.

Nilai keluaran fuzzy akan dimasukkan kedalam konstanta perhitungan kontrol proposional. Setelah mendaptkan hasil perhitungan kontrol proposional, maka nilai tersebut digunakan sebagai penentu kecepatan motor kanan dan kiri.

Dengan rumus :

$$
\begin{aligned}
& \text { MotorKiri }=\text { base_pwm }-\mathrm{P} \\
& \text { MotorKanan }=\text { base_pwm }+\mathrm{P}
\end{aligned}
$$

\section{IMPLEMENTASI DAN PENGUJIAN}

Implementasi sistem adalah hasil dari bagian perancangan, tahap yang membuat hasil dari perancangan sebelumnya. Pengujian dilakukan untuk menguji sistem apakah mampu bekerja sesuai dengan hasil perancangan yang telah dibuat dan mampu memberikan hasil pengolahan masukan dengan benar serta memberikan perilaku-perilaku serta keluaran sesuai kebutuhan. Pengujian dengan melakukan pada jalur berada di posisi tengah, kanan, dan jalur abu-abu.

Perangkat keras sistem yang telah dirancang sebelumnya akan diimplementasikan, mulai dari pembuatan sistem hingga pemasangan perangkat sistem keseluruhan. Hasil implementasi perangkat keras disajikan pada Gambar 6 setelah komponen dipasang dan Gambar 7 setelah keseluruhan sistem menjadi sebuah perangkat keras.

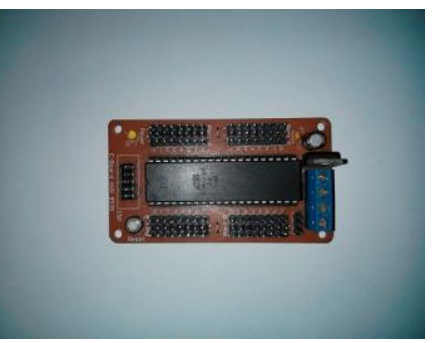

Gambar 6 Hasil implementasi perangkat keras sistem

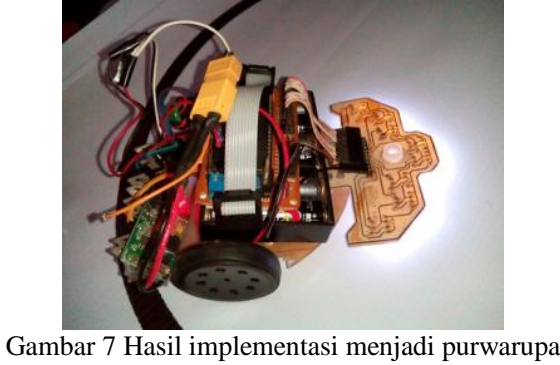

Langkah terakhir tahapan pengujian adalah melakukan analisa terhadap hasil uji yang telah dilakukan. Jalur yang digunakan dalam pengujian adalah jalur dengan perpaduan garis lurus dan garis setengah lingkaran. Analisa hasil pengujian diperlukan untuk memastikan kesesuaian sistem yang telah dibangun dengan perancangan, sehingga didapatkan sistem yang sesuai dengan perancangan. Analisa hasil pengujian juga berguna untuk melihat error pada sistem, jika ada, sehingga dapat dilakukan pembenahan error sistem tersebut.

Sensor akan membaca jalur dan didapat data yang akan dijadikan masukan fuzzy. Hasil dari fuzzyfikasi diolah lagi dengan menyesuaikan pada aturan dasar (rule base) yang menghasilkan keluaran singelton. Singeltonsingelton menjadi masukan defuzzyfikasi dan menghasilkan keluaran, konsekuen. Nilai konsekuen ini akan dijadikan parameter kendali proposional yang dikalikan dengan error, kondisi robot terhadap jalur.

Posisi jalur berada diposisi tengah robot. Setelah dijalankan robot berjalan lurus sehingga membuktikan sistem berjalan dengan baik pada kondisi jalur berada di tengah robot. Pada Gambar 8 ditunjukkan gambar jalur berada di tengah robot.

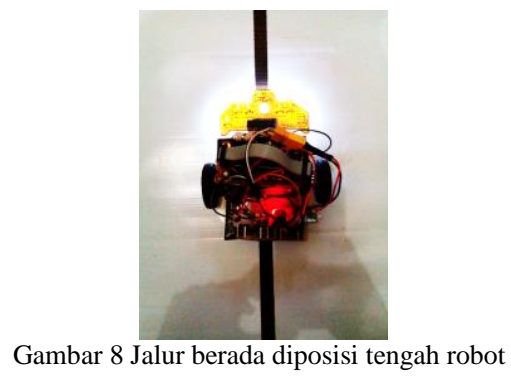

Dari hasil pengujian sensor 2 dan 5 berada pada derajat keanggotaan $\mathrm{k}$ dan $\mathrm{s}$ yang berarti tidak membaca latar jalur dengan warna putih, ini dapat disebabkan oleh sensor yang terlalu dekat dengan jalur atau sensor bermasalah. Hasil dari pengujian jalur di tengah robot adalah robot berjalan lurus dan dengan nilai error 0 . Setiap kondisi robot memiliki error yang berbeda. Dapat dilihat pada lampiran Tabel 1, Tabel 2, dan Tabel 3.

Posisi jalur berada diposisi kanan robot. Setelah dijalankan robot belok kanan sehingga membuktikan sistem berjalan dengan baik pada kondisi jalur berada diposisi kanan robot. Pada Gambar 9 ditunjukkan gambar pengujian jalur berada diposisi kanan robot. 


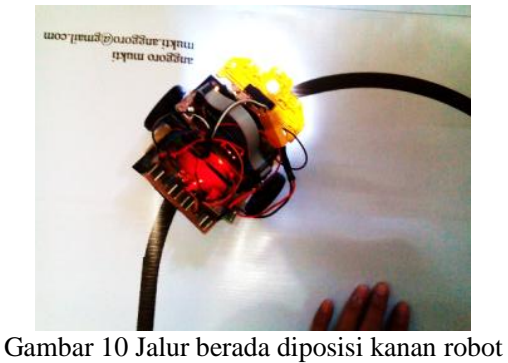

Dari hasil pengujian sensor 2 dan 5 pada waktu tertentu berada pada derajat keanggotaan $\mathrm{k}$ dan $\mathrm{s}$ yang berarti tidak membaca latar jalur dengan warna putih, ini dapat disebabkan oleh sensor yang terlalu dekat dengan jalur atau sensor bermasalah. Sensor 3 berada pada derajat keanggotaan $\mathrm{k}$ dan $\mathrm{s}$ yang berarti jalur dibaca sebagai warna tidak putih, ini dapat disebabkan sensor dekat dengan jalur. Hasil dari pengujian jalur di kanan robot adalah robot berbelok ke kanan dan dengan nilai error 4 . Setiap kondisi robot memiliki error yang berbeda. Dapat dilihat pada lampiran Tabel 4, Tabel 5, dan Tabel 6.

Posisi jalur berada diposisi kanan robot. Setelah dijalankan robot belok kanan sehingga membuktikan sistem berjalan dengan baik pada kondisi jalur abu-abu $50 \%$ berada diposisi kanan robot. Pada Gambar 11 ditunjukkan gambar pengujian jalur warna abu-abu $50 \%$ berada diposisi kanan robot.

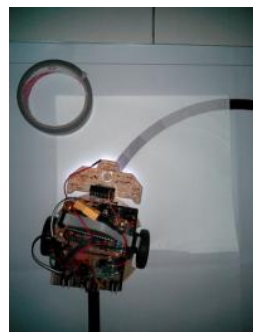

Gambar 10 Jalur warna abu-abu $50 \%$ berada diposisi kanan robot

Dari hasil pengujian sensor 4 berada pada derajat keanggotaan $\mathrm{b}$ dan $\mathrm{s}$ yang berarti membaca latar jalur dengan warna abu-abu. Sensor 3 berada pada derajat keanggotaan $\mathrm{k}$ dan $\mathrm{s}$ yang berarti jalur dibaca sebagai warna tidak putih, ini dapat disebabkan sensor dekat dengan jalur. Hasil dari pengujian jalur di kanan robot adalah robot berbelok ke kanan dan dengan nilai error 5 . Setiap kondisi robot memiliki error yang berbeda. Dapat dilihat pada lampiran Tabel 7, Tabel 8, dan Tabel 9.

Pengujian kecepatan motor kanan dan motor kiri ini untuk mengetahui perbandingan respon berdasarkan kecepatan sistem kontrol logika fuzzy dengan sistem kontrol konvensional. Sistem kontrol logika fuzzy memiliki kecepatan yang lebih dibandingkan dengan sistem kontrol konvensional.

Hasil pengujian kecepatan adalah pada jalur lurus dan jalur belok. Pada jalur lurus memiliki kecepatan yang sama yaitu kecepatan dasar. Pada jalur belok kecepatan yang dihasilkan sistem kontrol konvensional selalu tetap sedangkan pada sistem kontrol logika fuzzy memiliki kecepata yang berbeda-beda ini berarti sistem kontrol logika fuzzy memberikan respon yang tinggi terhadap kondisi jalur. Dapat dilihat pada lampiran Tabel 10.

\section{PENUTUP}

Dari hasil pengujian dan analisis sistem kontrol robot line follower dengan logika fuzzy, maka dapat diambil kesimpulan. Pertama logika fuzzy dapat diterapkan pada pergerakan sistem kontrol robot pengikut garis dengan proses inisialisasi masukan sensor. Masukan awal sistem ini adalah sensor fotodioda yang membaca jalur berwarna hitam dengan latar berwarna putih. Kedua, sistem kontrol logika fuzzy mampu mengidentifikasi jalur lurus, belok kanan, dan belok kiri. Robot dapat berbelok dengan mengurangi dan menambahkan hasil perhitungan logika fuzzy dengan kecepatan dasar, saat pembacaan jalur lurus. Ketiga, sistem kontrol logika fuzzy mampu mengidentifikasi jalur dengan tingkat kesulitan tertentu yaitu belokan setengah lingkaran dengan jari-jari $15 \mathrm{~cm}$, $20 \mathrm{~cm}$ dan $25 \mathrm{~cm}$. Keempat, sistem kontrol fuzzy mampu mengidentifikasi dan berjalan pada jalur abu-abu $50 \%$. Keempat sistem kontrol logika fuzzy memiliki respon yang lebih cepat terhadap jalur.

Beberapa saran yang dapat diberikan untuk pengembangan penelitian berikutnya. Desain prototype robot di buat dengan lebih memperhatikan letak antar komponen, sumbu roda belakang dan letak sensor sehingga gerakan semakin baik. Penggabungan metode kendali fuzzy dan metode PID akan lebih baik, karena error koreksi semakin baik. Sistem kontrol logika fuzzy dapat diterapkan pada robot fungsi lain, seperti robot pengikut cahaya, dengan sensor yang berbeda. Selain sugeno, logika fuzzy lainnya juga dapat diterapkan pada robot mobil, seperti mamdani atau tsukamoto

\section{DAFTAR PUSTAKA}

[1] G. McComb, Robot Builder's Bonanza, McGraw-Hill, New York, 2006

[2] T. D. S. Suyadhi, Buku Pintar Robotika, Andi, Yogyakarta, 2010.

[3] Ibrahim, D., Alshanableh, T., An Undergraduate Fuzzy Logic Control Lab Using a Line Following Robot, Wiley Periodicals Inc., Lefkosa. 2009.

[4] Malik, M. I. dan Juwana, M. U., Aneka Proyek Mikrokontroler PIC16F84/A, PT Elex Media Komputindo, Jakarta, 2009.

[5] Pandiangan, J., Perancanga dan Penggunaan Photodioda Sebagai Sensor Dinding pada Robot Forklift, Skripsi S-1, Universitas Sumatra Utara, Medan, 2007.

[6] Bartlet, Industrial Control Electronic, United State of America.Hal89, Delmar, 2002.

[7] Klir, G. J. dan Yuan Bo., Fuzzy Sets and Fuzzy Logics : Theory and Application, Prentice-Hall Inc., New Jersey, 1995.

[8] S. Kusumadewi, Analisis dan Desain Sistem Fuzzy, Graha Ilmu, Jogjakarta 2002.

[9] B. U. Atmaja, Harianto and Ihyaudin, "Rancang Bangun Robot Quadrapod Pendeteksi Halangan dengan Menggunakan Logika Fuzzy".

[10] S. Kusumadewi, Analisis dan Desain Sistem Fuzzy, Graha Ilmu, Jogjakarta 2002. 


\section{LAMPIRAN}

Tabel 1 Pengujian jalur di tengah robot pada sensor 1, 2, dan 3

\begin{tabular}{|c|c|c|c|c|c|c|c|c|c|c|c|c|}
\hline \multirow{3}{*}{ no } & \multicolumn{12}{|c|}{ Antesenden } \\
\hline & \multicolumn{4}{|c|}{1} & \multicolumn{4}{|c|}{2} & \multicolumn{4}{|c|}{3} \\
\hline & $\mathrm{N}$ & $\mathrm{k}$ & $\mathrm{S}$ & $\mathrm{b}$ & $\mathrm{N}$ & $\mathrm{k}$ & $\mathrm{s}$ & $\mathrm{b}$ & $\mathrm{N}$ & $\mathrm{k}$ & $\mathrm{s}$ & $\mathrm{b}$ \\
\hline 1 & 0 & 1 & 0 & 0 & 12 & 0,55 & 0,55 & 0 & 173 & 0 & 0 & 1 \\
\hline 2 & 0 & 1 & 0 & 0 & 19 & 0,73 & 0,28 & 0 & 190 & 0 & 0 & 1 \\
\hline 3 & 1 & 0,98 & 0,02 & 0 & 11 & 0,75 & 0,25 & 0 & 215 & 0 & 0 & 1 \\
\hline 4 & 1 & 0,98 & 0,02 & 0 & 10 & 0,73 & 0,28 & 0 & 182 & 0 & 0 & 1 \\
\hline 5 & 0 & 1 & 0 & 0 & 11 & 0,6 & 0,4 & 0 & 172 & 0 & 0 & 1 \\
\hline 6 & 0 & 1 & 0 & 0 & 16 & 0,63 & 0,38 & 0 & 167 & 0 & 0 & 1 \\
\hline 7 & 0 & 1 & 0 & 0 & 15 & 0,6 & 0,4 & 0 & 157 & 0 & 0 & 1 \\
\hline 8 & 0 & 1 & 0 & 0 & 16 & 0,55 & 0,45 & 0 & 176 & 0 & 0 & 1 \\
\hline 9 & 0 & 1 & 0 & 0 & 18 & 0,6 & 0,4 & 0 & 163 & 0 & 0 & 1 \\
\hline 10 & 0 & 1 & 0 & 0 & 16 & 0,58 & 0,43 & 0 & 156 & 0 & 0 & 1 \\
\hline 11 & 0 & 1 & 0 & 0 & 17 & 0,58 & 0,43 & 0 & 151 & 0 & 0 & 1 \\
\hline
\end{tabular}

Tabel 2 Pengujian jalur di tengah robot pada sensor 4, 5, 6, dan konsekuen

\begin{tabular}{|c|c|c|c|c|c|c|c|c|c|c|c|c|c|}
\hline \multirow{3}{*}{ no } & \multicolumn{12}{|c|}{ Antesenden } & \multirow{3}{*}{ Konsekuen } \\
\hline & \multicolumn{4}{|c|}{4} & \multicolumn{4}{|c|}{5} & \multicolumn{4}{|c|}{6} & \\
\hline & $\mathrm{N}$ & $\mathrm{k}$ & $\mathrm{s}$ & $b$ & $\mathrm{~N}$ & $\mathrm{k}$ & $\mathrm{s}$ & $\mathrm{b}$ & $\mathrm{N}$ & $\mathrm{k}$ & $\mathrm{s}$ & $\mathrm{b}$ & \\
\hline 1 & 181 & 0 & 0 & 1 & 17 & 0,58 & 0,43 & 0 & 0 & 0 & 0 & 1 & $-5,39$ \\
\hline 2 & 185 & 0 & 0 & 1 & 11 & 0,73 & 0,28 & 0 & 0 & 0 & 0 & 1 & $-5,42$ \\
\hline 3 & 221 & 0 & 0 & 1 & 13 & 0,68 & 0,33 & 0 & 0 & 0 & 0 & 1 & $-5,27$ \\
\hline 4 & 196 & 0 & 0 & 1 & 18 & 0,55 & 0,45 & 0 & 0 & 0 & 0 & 1 & $-5,37$ \\
\hline 5 & 205 & 0 & 0 & 1 & 24 & 0,4 & 0,6 & 0 & 0 & 0 & 0 & 1 & $-5,54$ \\
\hline 6 & 209 & 0 & 0 & 1 & 22 & 0,45 & 0,55 & 0 & 0 & 0 & 0 & 1 & $-5,62$ \\
\hline 7 & 204 & 0 & 0 & 1 & 18 & 0,55 & 0,45 & 0 & 0 & 0 & 0 & 1 & $-5,49$ \\
\hline 8 & 205 & 0 & 0 & 1 & 17 & 0,58 & 0,43 & 0 & 0 & 0 & 0 & 1 & $-5,49$ \\
\hline 9 & 205 & 0 & 0 & 1 & 17 & 0,58 & 0,43 & 0 & 0 & 0 & 0 & 1 & $-5,54$ \\
\hline 10 & 206 & 0 & 0 & 1 & 15 & 0,63 & 0,38 & 0 & 0 & 0 & 0 & 1 & $-5,44$ \\
\hline 11 & 239 & 0 & 0 & 1 & 18 & 0,55 & 0,45 & 0 & 0 & 0 & 0 & 1 & $-5,54$ \\
\hline
\end{tabular}

Tabel 3 Hasil pengujian jalur di tengah robot

\begin{tabular}{|c|c|c|c|}
\hline No & Konsekuen & e & Respon robot \\
\hline 1 & $-5,39$ & 0 & Lurus \\
\hline 2 & $-5,42$ & 0 & Lurus \\
\hline 3 & $-5,27$ & 0 & Lurus \\
\hline 4 & $-5,37$ & 0 & Lurus \\
\hline 5 & $-5,54$ & 0 & Lurus \\
\hline 6 & $-5,62$ & 0 & Lurus \\
\hline 7 & $-5,49$ & 0 & Lurus \\
\hline 8 & $-5,49$ & 0 & Lurus \\
\hline
\end{tabular}




\begin{tabular}{|c|c|c|c|}
9 & $-5,54$ & 0 & Lurus \\
\hline 10 & $-5,44$ & 0 & Lurus \\
\hline 11 & $-5,54$ & 0 & Lurus \\
\hline
\end{tabular}

Tabel 4 Hasil pengujian pada jalur di kanan robot dengan sensor 1, 2, dan 3

\begin{tabular}{|c|c|c|c|c|c|c|c|c|c|c|c|c|}
\hline \multirow{3}{*}{ no } & \multicolumn{12}{|c|}{ Antesenden } \\
\hline & \multicolumn{4}{|c|}{1} & \multicolumn{4}{|c|}{2} & \multicolumn{4}{|c|}{3} \\
\hline & $\mathrm{N}$ & $\mathrm{k}$ & $\mathrm{S}$ & $\mathrm{b}$ & $\mathrm{N}$ & $\mathrm{k}$ & $\mathrm{S}$ & $\mathrm{b}$ & $\mathrm{N}$ & $\mathrm{k}$ & $\mathrm{S}$ & $\mathrm{b}$ \\
\hline 1 & 0 & 1 & 0 & 0 & 0 & 0 & 0 & 0 & 28 & 0,3 & 0,7 & 0 \\
\hline 2 & 0 & 1 & 0 & 0 & 0 & 0 & 0 & 0 & 17 & 0,58 & 0,43 & 0 \\
\hline 3 & 0 & 1 & 0 & 0 & 0 & 0 & 0 & 0 & 18 & 0,55 & 0,45 & 0 \\
\hline 4 & 0 & 1 & 0 & 0 & 0 & 0 & 0 & 0 & 16 & 0,6 & 0,4 & 0 \\
\hline 5 & 0 & 1 & 0 & 0 & 0 & 0 & 0 & 0 & 21 & 0,48 & 0,53 & 0 \\
\hline 6 & 0 & 1 & 0 & 0 & 0 & 0 & 0 & 0 & 20 & 0,5 & 0,5 & 0 \\
\hline 7 & 0 & 1 & 0 & 0 & 0 & 0 & 0 & 0 & 23 & 0,43 & 0,58 & 0 \\
\hline 8 & 0 & 1 & 0 & 0 & 7 & 0,83 & 0,18 & 0 & 34 & 0,15 & 0,85 & 0 \\
\hline 9 & 0 & 1 & 0 & 0 & 7 & 0,83 & 0,18 & 0 & 15 & 0,63 & 0,38 & 0 \\
\hline 10 & 0 & 1 & 0 & 0 & 7 & 0,83 & 0,18 & 0 & 11 & 0,73 & 0,28 & 0 \\
\hline 11 & 0 & 1 & 0 & 0 & 9 & 0,78 & 0,23 & 0 & 22 & 0,45 & 0,55 & 0 \\
\hline
\end{tabular}

Tabel 5 Hasil pengujian pada jalur di kanan robot dengan sensor 3, 4, 5, dan konsekuen

\begin{tabular}{|c|c|c|c|c|c|c|c|c|c|c|c|c|c|}
\hline \multirow{3}{*}{ No } & \multicolumn{12}{|c|}{ Antesenden } & \multirow{3}{*}{ Konsekuen } \\
\hline & \multicolumn{4}{|c|}{4} & \multicolumn{4}{|c|}{5} & \multicolumn{4}{|c|}{6} & \\
\hline & $\mathrm{N}$ & $\mathrm{k}$ & $\mathrm{s}$ & $\mathrm{b}$ & $\mathrm{N}$ & $\mathrm{k}$ & $\mathrm{s}$ & $\mathrm{b}$ & $\mathrm{N}$ & $\mathrm{k}$ & $\mathrm{s}$ & $\mathrm{b}$ & \\
\hline 1 & 245 & 0 & 0 & 1 & 3 & 0,93 & 0,08 & 0 & 0 & 0 & 0 & 1 & $-3,53$ \\
\hline 2 & 236 & 0 & 0 & 1 & 3 & 0,93 & 0,08 & 0 & 0 & 0 & 0 & 1 & $-3,33$ \\
\hline 3 & 243 & 0 & 0 & 1 & 3 & 0,93 & 0,08 & 0 & 0 & 0 & 0 & 1 & $-3,36$ \\
\hline 4 & 233 & 0 & 0 & 1 & 2 & 0,95 & 0,05 & 0 & 0 & 0 & 0 & 1 & $-3,28$ \\
\hline 5 & 240 & 0 & 0 & 1 & 3 & 0,93 & 0,08 & 0 & 0 & 0 & 0 & 1 & $-3,43$ \\
\hline 6 & 232 & 0 & 0 & 1 & 0 & 1 & 0 & 0 & 0 & 0 & 0 & 1 & $-3,33$ \\
\hline 7 & 242 & 0 & 0 & 1 & 0 & 1 & 0 & 0 & 0 & 0 & 0 & 1 & $-3,41$ \\
\hline 8 & 236 & 0 & 0 & 1 & 0 & 1 & 0 & 0 & 0 & 0 & 0 & 1 & $-3,86$ \\
\hline 9 & 240 & 0 & 0 & 1 & 0 & 1 & 0 & 0 & 0 & 0 & 0 & 1 & $-3,38$ \\
\hline 10 & 235 & 0 & 0 & 1 & 0 & 1 & 0 & 0 & 0 & 0 & 0 & 1 & $-3,28$ \\
\hline 11 & 242 & 0 & 0 & 1 & 2 & 0,95 & 0,05 & 0 & 0 & 0 & 0 & 1 & $-3,61$ \\
\hline
\end{tabular}

Tabel 6 Hasil pengujian jalur di kanan robot

\begin{tabular}{|c|c|c|c|}
\hline No & Konsekuen & $\mathrm{e}$ & Respon robot \\
\hline 1 & $-3,53$ & 5 & Belok Kanan \\
\hline 2 & $-3,33$ & 5 & Belok Kanan \\
\hline 3 & $-3,36$ & 5 & Belok Kanan \\
\hline 4 & $-3,28$ & 5 & Belok Kanan \\
\hline 5 & $-3,43$ & 5 & Belok Kanan \\
\hline 6 & $-3,33$ & 5 & Belok Kanan \\
\hline 7 & $-3,41$ & 5 & Belok Kanan \\
\hline
\end{tabular}




\begin{tabular}{|c|c|c|c|}
8 & $-3,86$ & 5 & Belok Kanan \\
\hline 9 & $-3,38$ & 5 & Belok Kanan \\
\hline 10 & $-3,28$ & 5 & Belok Kanan \\
\hline 11 & $-3,61$ & 5 & Belok Kanan \\
\hline
\end{tabular}

Tabel 7 Hasil pengujian pada jalur abu-abu 50\% di kanan robot dengan sensor 1, 2, dan 3

\begin{tabular}{|c|c|c|c|c|c|c|c|c|c|c|c|c|}
\hline \multirow{3}{*}{ no } & \multicolumn{10}{c|}{ Antesenden } \\
\cline { 2 - 17 } & \multicolumn{3}{|c|}{1} & \multicolumn{10}{c|}{2} & \multicolumn{3}{c|}{3} \\
\cline { 2 - 16 } & $\mathrm{N}$ & $\mathrm{k}$ & $\mathrm{s}$ & $\mathrm{b}$ & $\mathrm{N}$ & $\mathrm{k}$ & $\mathrm{s}$ & $\mathrm{b}$ & $\mathrm{N}$ & $\mathrm{k}$ & $\mathrm{s}$ & $\mathrm{b}$ \\
\hline 1 & 0 & 1 & 0 & 0 & 0 & 0 & 0 & 0 & 18 & 0,55 & 0,45 & 0 \\
\hline 2 & 0 & 1 & 0 & 0 & 0 & 0 & 0 & 0 & 17 & 0,58 & 0,43 & 0 \\
\hline 3 & 0 & 1 & 0 & 0 & 0 & 0 & 0 & 0 & 18 & 0,55 & 0,45 & 0 \\
\hline 4 & 0 & 1 & 0 & 0 & 0 & 0 & 0 & 0 & 16 & 0,6 & 0,4 & 0 \\
\hline 5 & 0 & 1 & 0 & 0 & 0 & 0 & 0 & 0 & 17 & 0,58 & 0,43 & 0 \\
\hline 6 & 0 & 1 & 0 & 0 & 0 & 0 & 0 & 0 & 20 & 0,5 & 0,5 & 0 \\
\hline 7 & 0 & 1 & 0 & 0 & 0 & 0 & 0 & 0 & 23 & 0,43 & 0,58 & 0 \\
\hline 8 & 0 & 1 & 0 & 0 & 7 & 0,83 & 0,18 & 0 & 30 & 0,25 & 0,75 & 0 \\
\hline 9 & 0 & 1 & 0 & 0 & 7 & 0,83 & 0,18 & 0 & 15 & 0,63 & 0,38 & 0 \\
\hline 10 & 0 & 1 & 0 & 0 & 7 & 0,83 & 0,18 & 0 & 11 & 0,73 & 0,28 & 0 \\
\hline 11 & 0 & 1 & 0 & 0 & 9 & 0,78 & 0,23 & 0 & 22 & 0,45 & 0,55 & 0 \\
\hline
\end{tabular}

Tabel 8 Hasil pengujian pada jalur abu-abu 50\% di kanan robot dengan sensor 4, 5, dan 6

\begin{tabular}{|c|c|c|c|c|c|c|c|c|c|c|c|c|c|}
\hline \multirow{3}{*}{ no } & \multicolumn{12}{|c|}{ Antesenden } & \multirow{3}{*}{ Konsekuen } \\
\hline & \multicolumn{4}{|c|}{4} & \multicolumn{4}{|c|}{5} & \multicolumn{4}{|c|}{6} & \\
\hline & $\mathrm{N}$ & $\mathrm{k}$ & $\mathrm{s}$ & $\mathrm{b}$ & $\mathrm{N}$ & $\mathrm{k}$ & $\mathrm{s}$ & $\mathrm{b}$ & $\mathrm{N}$ & $\mathrm{k}$ & $\mathrm{s}$ & $\mathrm{b}$ & \\
\hline 1 & 87 & 0 & 0,57 & 0,43 & 3 & 0,93 & 0,08 & 0 & 0 & 0 & 0 & 1 & $-2,88$ \\
\hline 2 & 88 & 0 & 0,56 & 0,44 & 3 & 0,93 & 0,08 & 0 & 0 & 0 & 0 & 1 & $-2,9$ \\
\hline 3 & 88 & 0 & 0,56 & 0,44 & 0 & 1 & 0 & 0 & 0 & 0 & 0 & 1 & $-2,9$ \\
\hline 4 & 87 & 0 & 0,57 & 0,43 & 0 & 1 & 0 & 0 & 0 & 0 & 0 & 1 & $-2,8$ \\
\hline 5 & 88 & 0 & 0,56 & 0,44 & 0 & 1 & 0 & 0 & 0 & 0 & 0 & 1 & $-2,9$ \\
\hline 6 & 90 & 0 & 0,55 & 0,45 & 0 & 1 & 0 & 0 & 0 & 0 & 0 & 1 & $-2,9$ \\
\hline 7 & 88 & 0 & 0,56 & 0,44 & 0 & 1 & 0 & 0 & 0 & 0 & 0 & 1 & $-2,96$ \\
\hline 8 & 88 & 0 & 0,56 & 0,44 & 0 & 1 & 0 & 0 & 0 & 0 & 0 & 1 & $-3,14$ \\
\hline 9 & 87 & 0 & 0,57 & 0,43 & 0 & 1 & 0 & 0 & 0 & 0 & 0 & 1 & $-2,76$ \\
\hline 10 & 87 & 0 & 0,57 & 0,43 & 0 & 1 & 0 & 0 & 0 & 0 & 0 & 1 & $-2,66$ \\
\hline 11 & 88 & 0 & 0,56 & 0,44 & 2 & 0,95 & 0,05 & 0 & 0 & 0 & 0 & 1 & $-2,93$ \\
\hline
\end{tabular}

Tabel 9 Hasil pengujian jalur abu-abu 50\% di kanan robot

\begin{tabular}{|c|c|c|c|}
\hline No & Konsekuen & e & Respon robot \\
\hline 1 & $-2,88$ & 5 & Belok Kanan \\
\hline 2 & $-2,9$ & 5 & Belok Kanan \\
\hline 3 & $-2,9$ & 5 & Belok Kanan \\
\hline 4 & $-2,8$ & 5 & Belok Kanan \\
\hline 5 & $-2,9$ & 5 & Belok Kanan \\
\hline
\end{tabular}




\begin{tabular}{|c|c|c|c|}
6 & $-2,9$ & 5 & Belok Kanan \\
\hline 7 & $-2,96$ & 5 & Belok Kanan \\
\hline 8 & $-3,14$ & 5 & Belok Kanan \\
\hline 9 & $-2,76$ & 5 & Belok Kanan \\
\hline 10 & $-2,66$ & 5 & Belok Kanan \\
\hline 11 & $-2,93$ & 5 & Belok Kanan \\
\hline
\end{tabular}

Tabel 10 Hasil pengujian perbandingan kecepatan

\begin{tabular}{|c|c|c|c|c|c|}
\hline \multirow{2}{*}{ No } & \multicolumn{2}{|c|}{ Logika fuzzy } & \multicolumn{2}{|c|}{ Konvensional } & \multirow{2}{*}{ Respon robot } \\
\hline & Motor kanan & Motor kiri & Motor kanan & Motor kiri & \\
\hline 1 & 80 & 80 & 80 & 80 & Lurus \\
\hline 2 & 80 & 80 & 80 & 80 & Lurus \\
\hline 3 & 80 & 80 & 80 & 80 & Lurus \\
\hline 4 & 80 & 80 & 80 & 80 & Lurus \\
\hline 5 & 80 & 80 & 80 & 80 & Lurus \\
\hline 6 & 80 & 80 & 80 & 80 & Lurus \\
\hline 7 & 80 & 80 & 80 & 80 & Lurus \\
\hline 8 & 80 & 80 & 80 & 80 & Lurus \\
\hline 9 & 80 & 80 & 80 & 80 & Lurus \\
\hline 10 & 80 & 80 & 80 & 80 & Lurus \\
\hline 11 & 62,35 & 97,65 & 65 & 95 & Belok kanan \\
\hline 12 & 63,35 & 96,65 & 65 & 95 & Belok kanan \\
\hline 13 & 63,2 & 96,8 & 65 & 95 & Belok kanan \\
\hline 14 & 63,6 & 96,4 & 65 & 95 & Belok kanan \\
\hline 15 & 62,85 & 97,15 & 65 & 95 & Belok kanan \\
\hline 16 & 63,35 & 96,65 & 65 & 95 & Belok kanan \\
\hline 17 & 62,95 & 97,05 & 65 & 95 & Belok kanan \\
\hline 18 & 60,7 & 99,3 & 65 & 95 & Belok kanan \\
\hline 19 & 63,1 & 96,9 & 65 & 95 & Belok kanan \\
\hline 20 & 63,6 & 96,4 & 65 & 95 & Belok kanan \\
\hline
\end{tabular}

Keterangan

$$
\begin{array}{ll}
\mathrm{k} & =\text { Derajat keanggotaan kecil } \\
\mathrm{S} & =\text { Derajat keanggotaan sedang } \\
\mathrm{b} & =\text { Derajat keanggotaan besar } \\
\mathrm{N} & =\text { Nilai crisp } \\
\mathrm{e} & =\text { error, pembacaan kondisi robot terhadap jalur }
\end{array}
$$

